\title{
SISTEM INFORMASI KEUANGAN SESUAI STANDAR BAN-PT TERINTEGRASI SISFO KAMPUS 4.1
}

\author{
Syahiduzzaman, M. Ainul Yaqin, Nurul Misbah \\ Teknik Informatika UIN Maulana Malik Ibrahim Malang
}

\begin{abstract}
Abstrak-Standar keuangan adalah salah satu standar yang dinilai dalam instrumen BANPT, yaitu pada standar 6.1. Pengelolaan keuangan sebuah perguruan tinggi harus memenuhi standar tersebut. Untuk dapat mengetahui seberapa besar tingkat pemenuhan standar diperlukan penilaian. Sistem informasi keuangan yang dikembangkan dalam penelitian ini digunakan untuk memasukkan data transaksi keuangan, mencatatnya dalam sistem akuntansi, dan melaporkannya. Laporan-laporan yang disajikan berbentuk tabel dan grafik yang menyatakan kinerja keuangan dan diukur sesuai dengan standar 6.1. BAN-PT. Sistem informasi keuangan ini, juga terintegrasi dengan SISFOKAMPUS 4.1 yang merupakan sistem informasi akademik open source yang berbasis web. Hasil dari penelitian ini adalah sistem informasi keuangan dengan fungsi khusus yaitu menilai kinerja keuangan yang sesuai dengan standar 6.1. BAN-PT yang dapat digunakan untuk melakukan audit internal.
\end{abstract}

\section{Kata kunci: Standar 6.1. BAN-PT, Sistem Informasi Keuangan, SISFOKAMPUS 4.1.}

\section{PENDAHULUAN}

Keuangan adalah salah satu bagian dari hal yang memungkinkan suatu organisasi dapat menjalankan kegiatannya. Agar dapat diketahui arus kas keuangan, maka perlu adanya pengelolaan keuangan. Kegiatan pengelolaan keuangan dilakukan melalui proses perencanaan, pencatatan, pelaksanaan, pertanggung jawaban dan pelaporan. Dengan demikian, pengelolaan keuangan dapat diartikan sebagai rangkaian aktivitas mengatur keuangan mulai dari perencanaan, pembukuan, pembelanjaan, pengawasan dan pertanggung jawaban keuangan.

Menurut Undang-undang No 20 Tahun 2003 pasal 48 menyatakan bahwa pengelolaan dana pendidikan berdasarkan pada prinsip keadilan, efisiensi, transparansi, dan akuntabilitas publik. Disamping itu prinsip efektivitas juga perlu mendapat penekanan. Berikut ini dibahas masingmasing prinsip tersebut, yaitu transparansi, akuntabilitas, efektivitas, dan efisiensi.

Beberapa kegiatan pengelolaan keuangan yaitu memperoleh dan menetapkan sumber-sumber pendanaan, pemanfaatan dana, pelaporan, pemeriksaan dan pertanggung jawaban.

\section{A. Rumusan Masalah}

Rumusan masalah dalam penelitian ini adalah:

1. Bagaimana mengelola data keuangan perguruan tinggi secara terkomputerisasi?

2. Bagaimana mengintegrasikan sistem informasi keuangan dengan Sisfokampus 4.1?

3. Bagaimana melaporkan dan menilai kinerja keuangan perguruan tinggi berdasarkan standar 6 BAN-PT?

\section{B. Hipotesis}

Hipotesis dalam penelitian ini adalah :

1. Dengan adanya sistem informasi keuangan ini, maka masalah-masalah yang terkait dengan pegelolaan keuangan, pencatatan transaksi, akuntansi keuangan, anggaran keuangan, dan pelaporan keuangan dapat teratasi khususnya laporan kinerja keuangan yang sesuai dengan standar 6.1. BAN-PT.

2. Masalah integrasi sistem informasi keuangan dengan SISFOKAMPUS 4.1 dapat dilakukan dengan mengakses tabel-tabel yang dibutuhkan dalam database SISFOKAMPUS 4.1 dan melengkapinya dengan tabel-tabel yang dibutuhkan dalam sistem keuangan.

3. Dengan adanya sistem informasi keuangan ini, maka pelaporan dan penilaian kinerja keuangan perguruan tinggi dapat diotomasikan.

\section{Tujuan}

Tujuan penelitian ini adalah mengembangkan sistem informasi keuangan yang terintegrasi dengan Sisfokampus dengan pelaporan dan penilaian kinerja berdasarkan standar 6 BAN-PT.

D. Manfaat

1. Pengelolaan data secara terkomputerisasi akan mengurangi biaya operasional.

2. Integritas data lebih terjamin

3. Pembagian hak akses secara tepat dalam sistem informasi akan memperjelas tanggung jawab dan kewenangan setiap orang.

4. Setiap saat dapat memantau kinerja keuangan. 
5. Integrasi dengan SISFOKAMPUS 4.1 membuat kerja lebih efisien, dan mengurangi beban kerja personil.

\section{SISTEM INFORMASI KEUANGAN}

Sistem Informasi Keuangan adalah sistem informasi yang memberikan informasi kepada orang atau kelompok baik di dalam perusahaan maupun di luar perusahaan mengenai masalah keuangan. Dan Menyediakan informasi mengenai arus uang bagi para pemakai diseluruh perusahaan.

Sistem Informasi Keuangan yang akan nantinya diharapkan dapat mempermudah dan mempercepat kinerja bagi biro keuangan untuk melakukan proses pengelolaan keuangan. Proses yang ada pada sistem ini meliputi pendapatan atau uang kas masuk, pembelanjaan atau kas keluar yang meliputi pengadaan sarana prasarana kampus, penggajian dosen dan karyawan, biaya kegiatan lain serta pelaporan keuangan.

Sistem informasi ini akan dibangun menjadi sistem berbasis web yang dapat diakses oleh banyak user. Sistem ini akan diintegrasikan dengan Sisfo Kampus yang nantinya akan mempermudah bagi para user untuk mengambil data yang ada di Sisfo Kampus. Untuk perhitungan proses keuangan sistem ini menggunakan standart akuntansi yang ada pada perguruan tinggi. Sedangkan untuk penilaian akan digunakan standart mutu BAN-PT.

\section{STANDAR BAN-PT}

Program Akreditasi Ban-PT Tahun 2013 dilakukan selain terhadap program studi juga terhadap institusi Perguruan Tinggi Negeri/swasta. Dalam model Akreditasi program studi BAN-PT melakukan penilaian berdasarkan stantda-standar seperti dimensi input, proses, dan output serta outcome. Disamping itu juga berdasarkan standar akreditasi program studi seperti visi, misi, dan tujuan, pengelolaan Lembaga dan Program, dan lain-lain.

Dalam model Akreditasi institusi perguruan tinggi BAN-PT melakukan penilaian institusi perguruan tinggi dengan memperhatikan dua komitmen inti, yaitu: kapasitas institusi yang dicerminkan dalam ketersediaan dan kecukupan berbagai perangkat dasar yang diperlukan untuk menyelenggarakan pendidikan, seperti: eligibilitas, integritas, visi, misi, tujuan, dan sasaran, dan lainlain. Selanjutnya efektifitas pendidikan yang dicerminkan dengan tersedianya sejumlah masukan, proses dan suasana yang diperlukan dalam proses pendidikan serta produk kegiatan akademik seperti: kemahasiswaan, kurikulum, dan lain-lain.

Penelitian ini akan membahas tentang standar keuangan di perguruan tinggi yang terdiri atas penerimaan, pengeluaran dan sistem pertanggungjawaban anggaran yang digunakan dalam penyelenggaraan administrasi, program dan kegiatan perguruan tinggi. Standar keuangan meliputi sumber dana, sistem alokasi anggaran, sistem pertanggungjawaban, kecukupan anggaran pendidikan, pembangunan, penelitian dan pengabdian masyarakat.

\section{SISFOKAMPUS 4.1}

SisfoKampus merupakan suatu sistem informasi terintegrasi yang digunakan untuk mempermudah perguruan tinggi dalam mendukung proses penyelenggaraan pendidikan tinggi berbasiskan Teknologi Informasi dan Komunikasi (TIK). SisfoKampus merupakan aplikasi berbasiskan web (web-based application) yang dapat diakses menggunakan web.

Sistem Informasi Keuangan yang dibangun akan diintegrasikan dengan SisfoKampus untuk mempermudah user mengakses dan mengambil data yang ada di Sisfo Kampus. Integrasi dilakukan dengan cara menggabungkan antara tabel sistem informasi dengan tabel yang ada di SisfoKampus. Pada database SisfoKampus ada beberapa tabel yang berhubungan dengan keuangan, tetapi belum ada modul di SisfoKampus yang dapat digunakan untuk memanajemen tabel tersebut, maka dari itu dibuatlah modul pada sistem informasi keuangan yang berfungsi untuk memanajemen tabel tersebut, sehingga tabel tersebut bisa digunakan. 


\section{LINGKUP PROYEK}

Tabel 1. Lingkup Proyek Sistem Informasi Keuangan

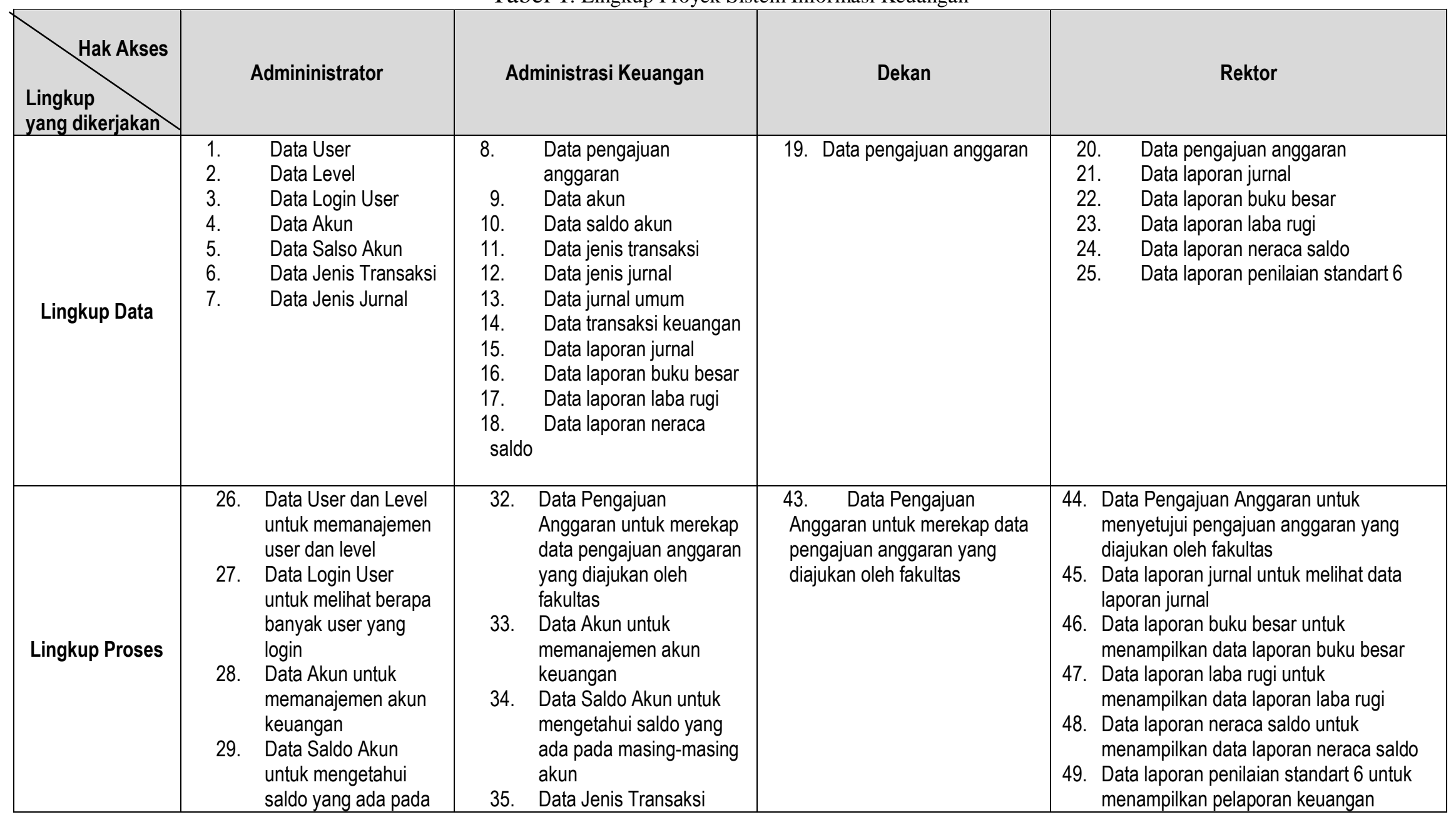




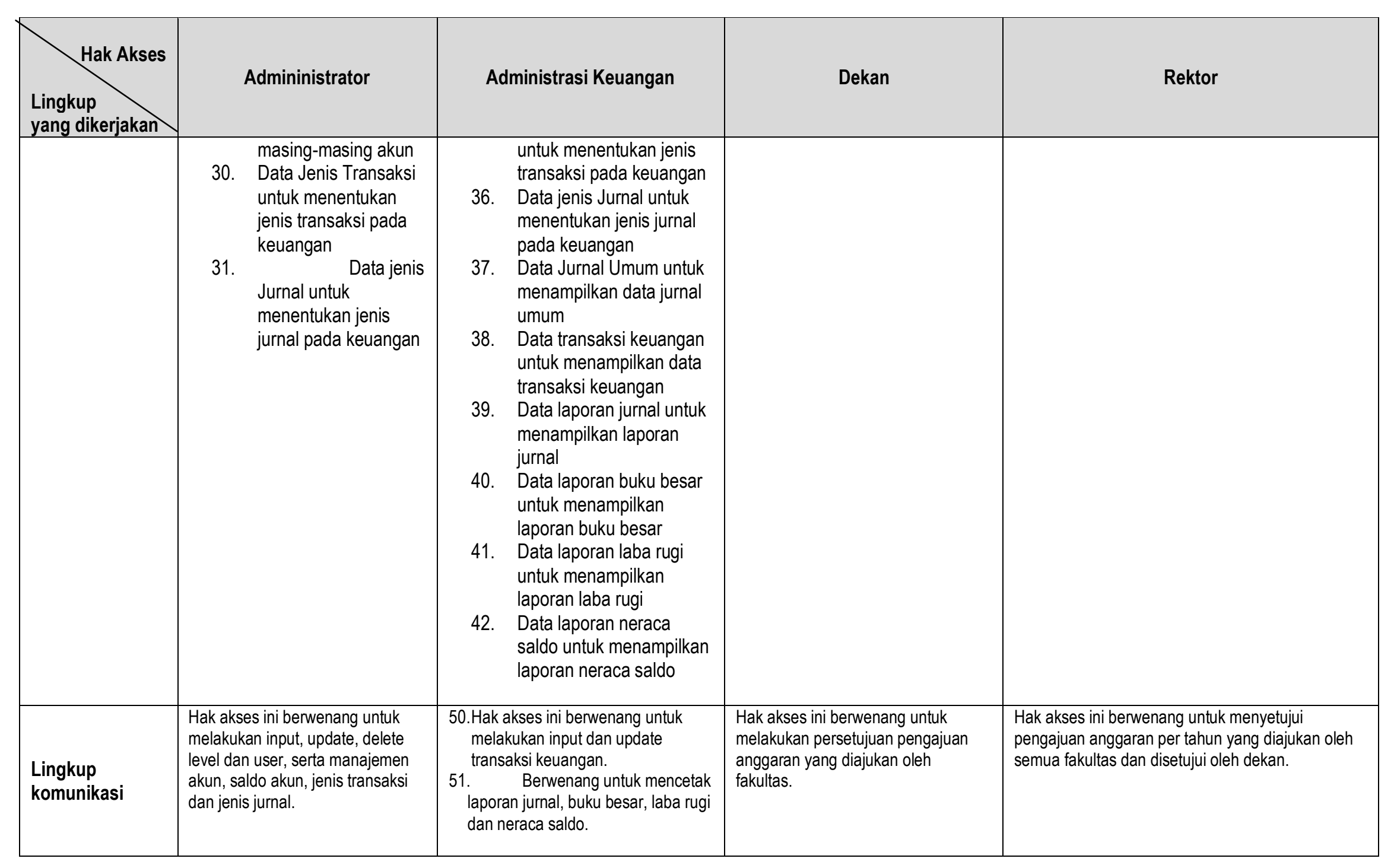




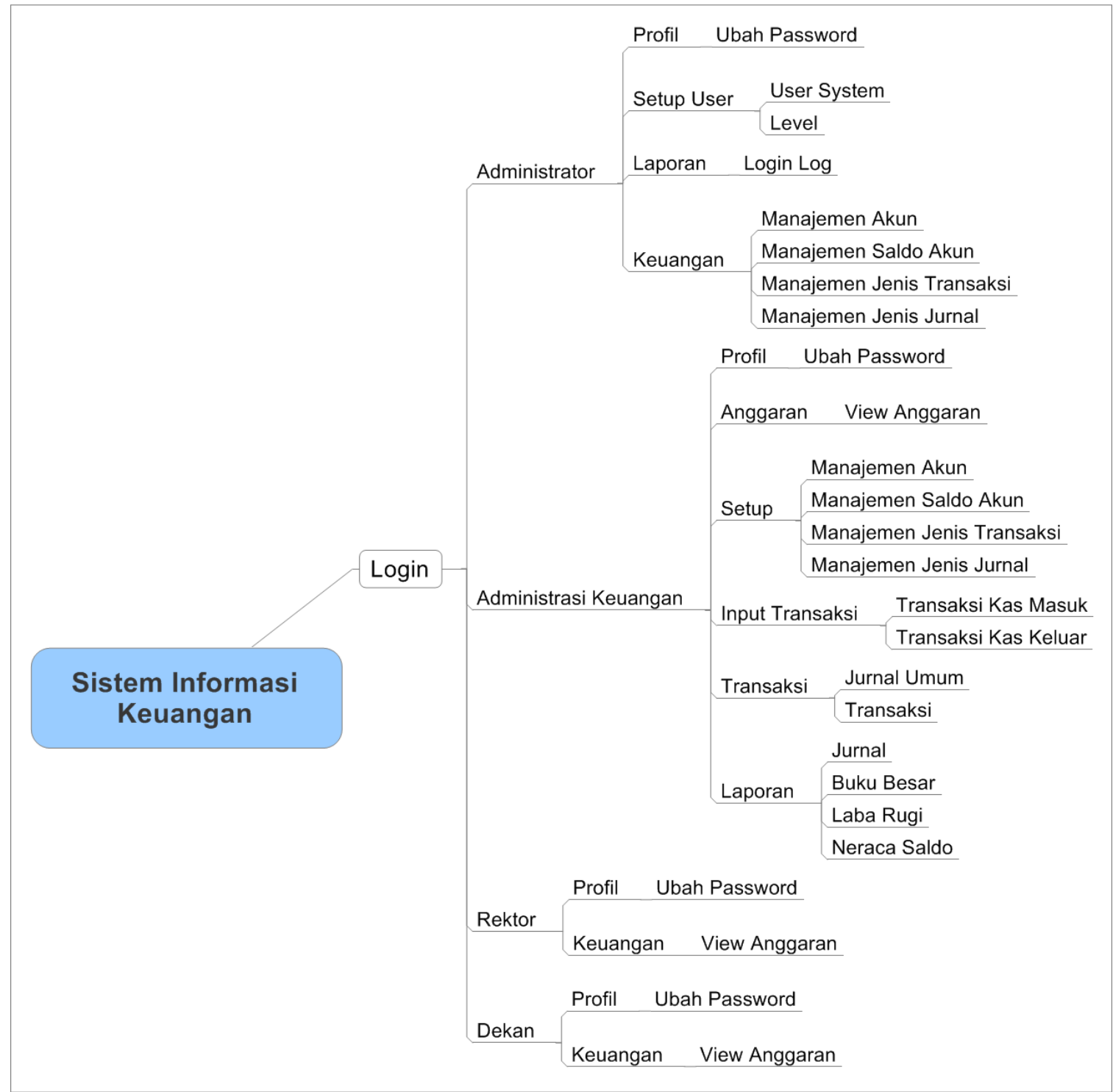

Gambar 1. Sitemap Sistem Informasi Keuangan 
ENTITY RELATIONSHIP DIAGRAM

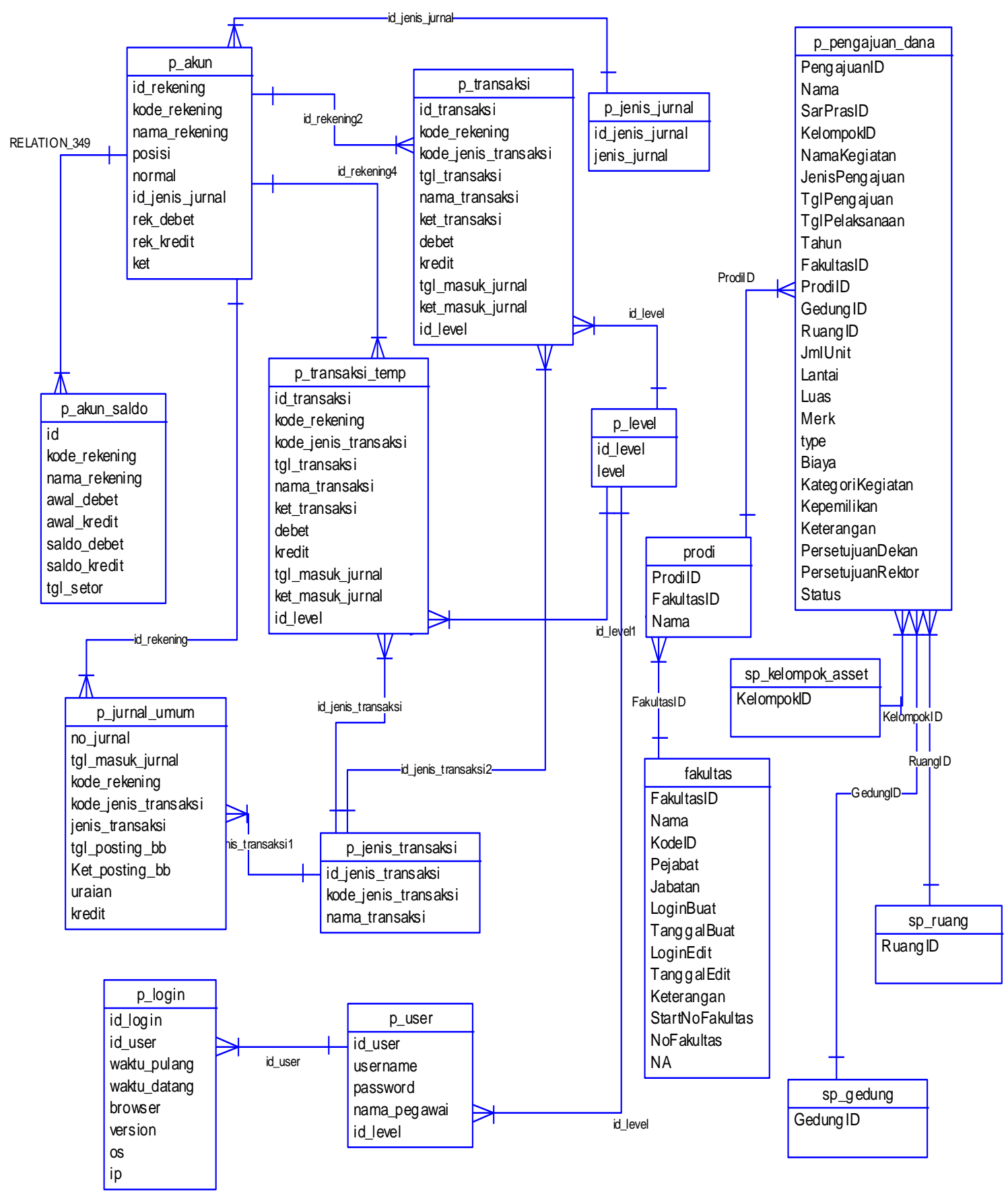

Gambar 2. ERD Sistem Informasi Keuangan

\section{HASIL DAN PEMBAHASAN}

Berdasarkan pengujian yang telah dilakukan oleh peneliti melalui pengujian alfa dengan metode Blackbox Testing, dari total item pengujian sebanyak 18, diperoleh hasil pengujian dengan prosentase $94.44 \%$ untuk nilai $\mathrm{S}$ (Sesuai) dan $5.56 \%$ untuk nilai TS (Tidak Sesuai). Nilai S (Sesuai) menyatakan bahwa pengujian yang

dilakukan hasilnya sesuai dengan standar pengujian. Sedangkan pada hasil TS (Tidak Sesuai) ketika dilakukan pengujian terdapat beberapa hasil output yang masih belum sesuai dengan standar pengujian.

Hasil dari penelitian ini adalah Sistem Informasi Keuangan yang terintegrasi dengan SISFOKAMPUS 4.1. Sistem informasi keuangan yang dikembangkan ini memiliki beberapa fitur yaitu:

1. Terintegrasi dengan SISFOKAMPUS 4.1 sehingga data-data akademik yang terkait dengan keuangan dapat langsung diakses dan diolah menurut keperluannya. Data-data tersebut adalah: data mahasiswa yang 
terhubung dengan transaksi pembayaran SPP, uang gedung, uang SKS, uang ujian, uang wisuda, dan lain-lain. Data dosen yang terhubung dengan transaksi pembayaran gaji yang terkait dengan beban mengajar, dan lainlain.

2. Sistem informasi keuangan ini disesuaikan dengan proses penganggaran secara umum, mulai dari pengajuan anggaran hingga laporan pertanggung jawaban anggaran.

3. Sistem informasi keuangan ini mengikuti prinsip-prinsip akuntansi, sehingga laporan keuangan yang dihasilkan juga sesuai dengan standar akuntansi.

4. Standar 6.1 BAN-PT yang mengatur masalah kinerja keuangan juga diadopsi oleh sistem informasi keuangan ini sebagai kontrol dan audit internal bagi perguruan tinggi yang menggunakannya.

Dengan demikian dapat dikatakan bahwa proses bisnis keuangan yang ada dalam suatu perguruan tinggi dapat dilayani oleh sistem informasi keuangan ini.

SISFOKAMPUS 4.1 digunakan sebagai dasar bagi pengembangan sistem informasi yang lainnya, hal ini disebabkan oleh SISFOKAMPUS 4.1 adalah sistem informasi yang melayani berlangsungnya sistem akademik dalam perguruan tinggi. Dari sistem akademik tersebut kemudian berkembang menjadi berbagai macam kebutuhan sistem informasi, salah satunya adalah masalah keuangan. Dalam penelitian ini berhasil dilakukan integrasi antara sistem informasi keuangan dengan SISFOKAMPUS 4.1. Integrasi dilakukan pada bagian database, yaitu dengan mengakses tabeltabel yang diperlukan untuk pengolahan data keuangan dan menambahkan tabel-tabel baru yang belum ada di dalam database SISFIKAMPUS 4.1. Integrasi antara kedua sistem informasi ini telah berhasil dilakukan.

Penerapan standar 6.1. BAN-PT dalam sistem informasi keuangan sebagai aturan dalam penilaian kinerja keuangan dan tata cara pelaporannya. Fitur ini sangat berguna untuk mengetahui kinerja keuangan dari perguruan tinggi yang menggunakannya. Dari nilai kinerja tersebut kemudian dapat digunakan oleh pengambil keputusan sebagai dasar dalam mengambil keputusan atau kebijakan yang terkait dengan keuangan.

\section{KESIMPULAN}

Dari hasil penelitian yang telah dilakukan dan pembahasan Sistem Informasi Keuangan berbasis web, diperoleh kesimpulan sebagai berikut:

1. Perancangan Sistem Informasi Keuangan telah selesai dibuat dan diuji, system yang dibuat dapat mencetak laporan keuangan sesuai dengan kebutuhan.
2. Sistem informasi keuangan dibuat dengan bahasa pemrograman web yang terintegrasi dengan Sisfo Kampus 4.1 dan dapat diakses oleh banyak pengguna, sehingga dapat mempercepat proses pengolahan keuangan.

3. Sistem informasi keuangan yang dibuat telah disesuaikan dengan standart BAN-PT, sehingga dapat memberikan nilai evaluasi bagi para pejabat institusi.

4. Hasil pengujian alfa dengan metode Blackbox Testing pada sistem informasi keuangan yang telah dibuat menyatakan $94.44 \%$ sesuai standar pengujian dan hasil $5.56 \%$ tidak sesuai.

\section{DAFTAR PUSTAKA}

[1] Al Fatta, Hanif. 2007. Analisis dan Perancangan Sistem Informasi. Yogyakarta: ANDI.

[2] BAN-PT Buku 2. 2008. Standart dan Prosedur Akreditasi. Jakarta.

[3] Djarwanto Ps, Drs.2002.Pokok-Pokok Analisis Laporan Keuangan Edisi2.Yogyakarta:BPFE - Yogyakarta.

[4] Dwi, P. D. 2008. Pemrograman PHP Buku Kedua. Jakarta. Gramedia.

[5] Jusup, Al Haryono.2003.Dasar-dasar Akuntansi Jilid 1.Yogyakarta:Sekolah Tinggi Ilmu Ekonomi YKPN.

[6] Kadir, A. (2003). Pengenalan Sistem Informasi. Yogyakarta: Andi.

[7] Kendall, K. E. (2003). Analisis dan Perancangsn Sistem. Jakarta: Indeks.

[8] Krismiaji.2002.Sistem Informasi Akuntansi, Edisi 1.Yogyakarta:Unit Penerbit dan Percetakan AMP YKPN.

[9] Ladjumudin, Al-Bahra bin. 2005. Analisis dan Desain Sistem Informasi. Yogyakarta: Graha Ilmu.

[10] Nugroho, A. (2004). Basis Data. Bandung: Informatika.

[11] Pressman RS. 2005. Software Engineering, a Practitioner's Approach. Edisi ke-6. McGrawHill.

[12] Suprianto, D. 2008. Buku Pintar Pemrograman PHP. Bandung. Oase Media. 
[13] Wahyono, Teguh. 2004. Sistem Informasi (Konsep Dasar, Analisis Desain dan Implementasi ). Yogyakarta: Graha Ilmu.
[14] Whitten, J. L. (2004). Metode Desain dan Analisis Sistem. Yogyakarta: ANDI.

[15] Williams, Laurie. 2006. White-Box Testing. 